\title{
Pelatihan Penyusunan RPP dan Bahan Ajar Bagi Guru Untuk Meningkatkan Kualitas Pembelajaran di Masa Pandemi
}

\author{
Moch. Sukardjo ${ }^{1 *}$, Uswatun Khasanah ${ }^{2}$, Etin Solehatin ${ }^{1}$, Yayan Sudrajat ${ }^{3}$ \\ ${ }^{1}$ Teknologi Pendidikan, Program Pasca Sarjana, Universitas Negeri Jakarta, \\ Jln Rawamangun Muka, Jakarta Timur, 13220 \\ ${ }^{2}$ Pendidikan Guru Sekolah Dasar, Fakultas Sosial dan Humaniora, Universitas Nahdlatul Ulama \\ Lampung, Mataram Marga, Sukadana, Kabupaten Lampung Timur, Lampung, 34194 \\ ${ }^{4}$ Pendidikan Bahasa Indonesia, Universitas Indraprasta PGRI, \\ TB Simatupang, Jalan Nangka Raya, Jagakarsa, Jakarta Selatan. 12530 \\ Email Penulis Korespondesi: msoekardjo@unj.ac.id
}

\begin{abstract}
A teacher in an education unit must write and compile a complete and sequential lesson plan (RPP) to create interactive, inspirational, fun, and not boring learning and provide new challenges for students. Also, it is to support students to participate, as well as to provide opportunities for students to take the initiative, in creativity, independently owned by students regarding their interests, talents, and physical and psychological development. This training activity aims to improve skills in compiling and writing lesson plans and teaching materials in improving the quality of learning during the pandemic. The method of implementing this training activity is boldly through discussion and question and answer as well as exercises and assignments to prepare lesson plans and teaching materials. The results showed that the enthusiasm of the teachers was high and after participating in this training $100 \%$ of all teachers wanted to write and compile plans for implementing learning to be brave and teaching materials, 75\% of teachers also increased the increase in work productivity, as many as 58.3\% hoped that there would be discussions among teachers. Who participated in this training and to be able to improve services to students as much as $83.3 \%$.
\end{abstract}

\section{Keyword: Learning Implementation Plan, Teaching Materials, Learning Quality}

\begin{abstract}
Abstrak
Seorang guru pada satuan pendidikan memiiki kewajiban menulis dan menyusun Rencana Kegiatan Pelaksanaan Pembelajaran (RPP) dengan lengkap dan berurutan demi terciptanya pembelajaran yang interaktif, inspiratif, menyenangkan dan tidak membosankan serta memberi tantangan yang baru untuk peserta didik. Di samping itu hal tersebut juga untuk mensuport peserta didik supaya aktif dan berpartisipasi, sera dapat memberikan kesempatan terhadap peserta didik untuk berinisiatif, dalam berdaya cipta, secara independensi yang dimiliki dalam diri peserta didik terkati minat, bakat dan perkembangan fisik serta psikologisnya. Kegiatan pelatihan ini bertujuan untuk meningkatkan keterampilan menyusun dan menulis rencana pelaksanaan pembelajaran dan bahan ajar dalam peningkatan kualitaas pembelajaran dimasa pandemi. Metode pelaksanaan kegiatan pelatihan ini adalah secara daring via zoom dengan diskusi dan Tanya jawab serta latihan dan penugasan untuk menyusun RPP dan Bahan Ajar. Hasil evaluasi menunjukkan bahwa antusiasme guru tinggi, setelah mengikuti pelatihan ini $100 \%$ semua guru ingin dapat menulis dan menyusun rencana pelaksanaan pembelajaran untuk daring dan bahan ajar, $75 \%$ sebagian guru juga menginginkan peningkatan dalam produktivitas kerja, sebanyak 58,3\% berharap adanya diskusi sesame guru yang ikut dalam pelatihan ini dan untuk dapat meningkatkan pelayanan pada siswa sebanyak $83.3 \%$
\end{abstract}

Kata kunci: Rencana Pelaksanan Pembelajaran, Bahan Ajar, Kualitas Pembelajaran 


\section{PENDAHULUAN}

Masa pandemi yang saat ini sedang kita alami disebabkan oleh penyebaran virus Covid19 , yang tidak hanya melanda satu wilayah namun tersebar luas diseluruh dunia. Sejak per tanggal 11 Juni 2020, kasus dengan positif terkena virus Covid-19 sudah mencapai 12.286, 264 jiwa yang tersebar di seluruh dunia. Di Indonesia, mencapai angka 74,018 jiwa yang terkonfirmasi positif terkena Covid-19. Populasi siswa di dunia lebih dari $91 \%$ telah terdampak dari penutupan sekolah dikarenakan oleh pandemi covid-19 (UNESCO). Semakin meningkatnya persebaran covid pada awal maret 2020. Indonesia, melalui pemerintah telah menetapkan anjuran agar bekerja, belajar dan beribadah dari rumah. Kondisi dan kebjikakan ini berdampak di setiap aspek kehidupan masyarakat, dan diantaranya yang terkena dampaknya adalah sektor pendidikan. Data yang didapat dari Kemendikbud RI, sejak ada penetapan program belajar dari rumah $(\mathrm{BdR})$ diseluruh wilayah Indonesia, oleh karenanya sebanyak 534.630 satuan pendidikan di tutup dalam melakukan kegiatan pembelajaran secara tatap muka. Terdapat 68,729.037 siswa yang diperkirakan melakukan BdR juga terdapat 4.183.591 guru karena terdampak oleh pandemi Covid-19.

Bekerja di rumah saat kodisi pandemi ini akan diasumsikan menjadi budaya kerja yang normal bagi semua lapisan masyarakat terutama di dunia pendidikan mereka yakni adalah guru dan siswa. Seseorang dengan profesi guru yang ada di seluruh Indonesia tetap harus mengerjakan tugasnya sebagai pendidik dari rumahnya (secara terus menerus dan menjadi rutinitas yang terkendali) secara kontinyu, mereka di tuntut untuk bekerja secara produktif dengan lingkungan baru tanpa adanya pengawasan dari pimpinan. Kegiatan belajar yang semula dilakukan dengan tatap muka (synchronous), dan pada situasi pandemi dilakukan dengan tanpa tatap muka (unsychronous). Proses pembelajaran tanpa tatap muka dilakukan dengan online (dalam jaringan) dan luring (luar jaringan), dan guru harus dapat mengkombinasikan keduanya. Untuk menyiapkan proses pembelajaran yang dilakukan dengan online (daring), guru dituntut untuk kapabel dalam mempersiapkan pembelajaran dengan membuat Rencana
Pelaksanaan Pembelajaran dan bahan ajar yang dikolaborasikan yang disesuaikan dengan kondisi dan situasi di tengah pandemi secara daring maupun luring.

Seorang guru harus mampu dalam merencanakan pembelajaran, melaksanakan kegiatan pembelajaran yang bermakna dan berkualitas dalam menyiasati dan mempersiapkan penyusunan RPP dan bahan ajar di tengah masa pandemi ini. Kegiatan proses pembelajaran yang berkualitas tentunya berkaitan bagaimana kesiapan guru dalam menentukan strategi pembelajaran yang tepat saat pandemi. Akan tetapi hal yang terjadi dilapangan, masih banyak guru yang masih kesulitan dalam menyusun dan menyiapkan RPP serta bahan ajar pada saat pendemi seperti saat ini. Adapun kesulitan yang dihadapi oleh guru diantaranya sebagai berikut: 1) membedakan RPP online dan RPP yang biasanya digunakan dalam pembelajaran tatap muka di kelas sebelum adanya pandemi; 2) umumnya guru belum pernah mengikuti pelatihan penyusunan RPP untuk pembelajaran online (daring) sehingga guru merasa kesulitan merancang kegiatan pembelajaran daring; 3) guru juga menemui kesulitan bagaimana penilaian kegiatan pembelajaran daring; 4) kesulitan lainnya bagi guru adalah sulitnya mencari rujukan utama untuk merancang RPP pembelajaran daring; 5) Guru juga masih merasa kesulitan menentukan strategi pembelajaran daring. Di samping itu guru juga masih merasa kesulitan dalam menyiapkam bahan ajar daring. Apakah bahan ajar tersebut sama dengan bahan ajar yang biasa di gunakan di kelas atau memang ada perbedaan. Kendala yang dialami oleh guru tersebut menjadi salah satu permasalahan dalam kehidupan proses pembelajaran guru pada masa pandemi Covid19.

Adanya kendala dalam menyusun RPP dan Bahan Ajar tersebut menyebabkan guru menjadi kesulitan dan tidak maksimal dalam melaksanakan kegiatan interaksi belajar mengajar yang dilakukan secara daring maupun luring. Oleh karena itu dampaknya pada siswa banyak materi pembelajaran yang telah direncanakan guru tidak dapat disampaikan dengan baik kepada siswa. Masih banyak guru yang belum dapat menyusun RPP dan bahan ajar bukan karena mereka tidak dapat menyusun RPP dan bahan ajar dengan baik, akan tetapi dikarenakan mengenai 
ketidaksiapan guru dalam menghadapi sistem pembelajaran yang secara daring dan serba mendadak tanpa adanya pelatihan maupun pembinaan sebelumnya karena situasi pandemi. Proses pembelajaran pada kondisi pandemi yang semuanya dengan sistem membuat guru harus belajar menggunakan teknologi internet via (zoom, google meeting) banyak guru yang tidak dapat mengoperasikan aplikasi tersebut dalam proses pembelajaran. Banyak guru yang masih kesulitan dalam menyampaikan materi pembelajaran dengan kegiatan belajar yang harus praktek.

Seyogyanya penyusunan RPP dan bahan ajar harus direncanakan dengan baik dan detail oleh guru sebelum pembelajaran dimulai. Apabila hal tersebut dilakukan, maka materi pembelajaran yang disampaikan guru akan dapat di terima oleh siswa sesuai dengan tujuan pembelajaran yang diharapkan. Oleh karenanya, melalui kegiatan pengabdian masyarakat yang dilakukan oleh dosen dan mahasiswa ini, mempunyai tujuan untuk membekali guru dengan pengetahuan dan keterampilan dalam menyusun RPP, membekali guru dengan pengetahuan dan ketrampilan dalam mengajar, membekali guru dengan pengetahuan dan keterampilan dalam memanfaatkan RPP yang dikembangkan, membekali guru dengan pengetahuan dan keterampilan dalam menilai RPP yang dikembangkan dalam proses pembelajaran, membekali guru dalam proses perancangan Bahan Ajar yang dikembangkan tenaga pendidik dalam proses pembelajaran sesuai kebutuhan dan karakteristiknya. Pemerintah Indonesia melalui Kemendikbud tetap ingin memberikan pelayanan pendidikan bagi anakanak meskipun saat kondisi pandemi sedang berlangsung. Oleh karenanya penting diadakannya pelatihan bagi guru dalam memenuhi kebutuhan belajar untuk parsiswanya. Meskipun belajar dilakukan dari rumah masing-masing tetap harus berjalan dengan seperti biasanya dalam pemenuhan dan pencapaian tujuan pembelajaran. Dengan diberikannya pelatihan terhadap guru diharapkan guru akan dapat menyusun RPP dan bahan Ajar dengan baik dan dapat melaksanakan kegiatan pembelajaran secara daring dan luring dengan bermakna dan berkualitas dimasa pandemi covid-19.

\section{METODE PELAKSANAAN}

Metode yang digunakan dalam kegiatan ini adalah berupa pelatihan. Sasaran kegiatan ini adalah guru SMKN 49 Dinas Provinsi Daerah Khusus Ibukota Jakarta untuk meningkatkan keterampilan dalam penyusunan Rencana Pelaksanaan Pembelajaran dan Bahan Ajar selama kondisi pandemi. Adapun metode yang akan dilakukan untuk mendukung keberhasilan pengabdian masyarakat ini, sebagai berikut:

a. Secara daring (via zoom)

Metode ini digunakan dalam kegiatan untuk menjelaskan teoritik pengetahuan secara umum tentang penyusunan keterampilan penyusunan Rencana Pelaksanaaan pembelajaran dan Bahan Ajar.

b. Diskusi dan Tanya jawab Metode ini digunakan untuk diskusi bagaimana penyusunan tentang keterampilan penyusunan Rencana Pelaksanaaan Pembelajaran dan Bahan Ajar.

c. Latihan/praktek/Penugasan

Metode ini digunakan untuk para peserta dalam mempraktekkan kegiatan menyusun Rencana Pelaksanaaan pembelajaran dan Bahan Ajar dengan baik melalui email kepada panitia pengabdian masyarakat.

\section{Waktu dan Tempat Pelaksanaan}

Waktu pelaksanaan pengabdian masyarakat ini dilakukan pada tanggal 12 Sepetember 2020 dilakukan secara daring

\section{Alat dan Bahan \\ Alat dan bahan yang digunakan dalam pelaksanaan kegiatan pengabdian masyarakat ini adalah. Media laptop dengan berbagai merk untuk dapat mengakses aplikasi zoom yang digunakan untuk pelatihan, media internet dan kertas serta alat tulis.}

\section{Langkah pelaksanaan}

Pelaksanaan kegiatan pengabdian masyarakat ini dilakukan dalam bentuk pelatihan secara daring via zoom.

1. Langkah pertama: narasumber memberikan penjelasan materi mengenai teori dan 
langkah-langkah dalam penyusunan rencana pelaksanaan pembelajaran dan bahan ajar.

2. Langkah kedua: setelah selesai pemaparan materi dilanjutkan dengan sesi Tanya jawab dan diskusi dengan peserta pelatihan

3. Langkah ketiga: penugasan atau latihan bagi para peserta pelatihan dalam menulis dan menyusun rencana pelaksanaan pembelajaran dan bahan ajar.

\section{HASIL DAN PEMBAHASAN}

\section{Rencana Pelaksanaan Pembelajaran dan Bahan Ajar}

Berdasarkan diskusi dari tim pengabdian masyarakat yang dilakukan oleh Dosen dan mahasiswa, terdapat kesepakatan dalam memenuhi kebutuhan para guru dimasa pandemi Covid -19 ini, dalam rangka peningkatan proses pembelajaran yang bermutu dan berkualitas meskipun para siswa melaksanakan belajar dengan dirumah masingmasing. Berdasarkan hasil kuisioner dari para peserta dihasilkan bahwa pentingnya dalam menyusun rencana pelaksanaa pembelajaran dan bahan ajar.

\section{Monitoring dan Evaluasi}

Terdapat 12 guru yang berpartisipasi dalam penelitian ini. Berdasarkan hasil kuisioner yang didapat dari tim pelatihan pengabdian masyarakat, terdapat $66.7 \%$ guru yang pernah mengikuti pelatihan penyusunan RPP, tetapi pada pelaksanaan kegiatannya dilakukan secara tatap muka sebanyak 87,5\%. hasil tersebut menunjukkan bahwa, antusiasme guru dalam mengikuti pelatihan penyusunan rencana pelaksanaan pembelajaran dan bahan ajar secara daring sangat diminati, hal ini dikarenakan kondisi pandemi Covid-19 yang sedang dialami oleh masyarakat diseluruh dunia. Para guru merespon dengan baik dengan adanya pelatihan penyusunan rencana pelaksanaan pembelajaran dan bahan ajar secara daring untuk memenuhi keberhasilan kegiatan pembelajaran selama pandemi Covid19.

Setelah mengikuti pelatihan ini $100 \%$ semua guru ingin dapat menulis dan menyusun rencana pelaksanaan pembelajaran dan bahan ajar, $75 \%$ sebagian guru juga menginginkan peningkatan dalam produktivitas kerja, sebanyak 58,3 \% berharap adanya diskusi sesama guru yang ikut dalam pelatihan ini dan untuk dapat meningkatkan pelayanan pada siswa sebanyak $83,3 \%$. Dan sebanyak $11,1 \%$ para guru merespon untuk hal lainnya. Berdasarkan hasil kuisioner dari para peserta menunjukkan bahwa respon yang tinggi karena pentingnya pelatihan dalam menyusun rencana pelaksanaan pembelajaran dan bahan ajar untuk meningkatkan kualitas pembelajaran dimasa pandemi Covid-19 secara daring/online yang sangat dibutuhkan oleh siswa dalam pencapaian tujuan pembelajaran meskipun siswa dalam proses belajarnya dilakukan dirumah (belajar dirumah).

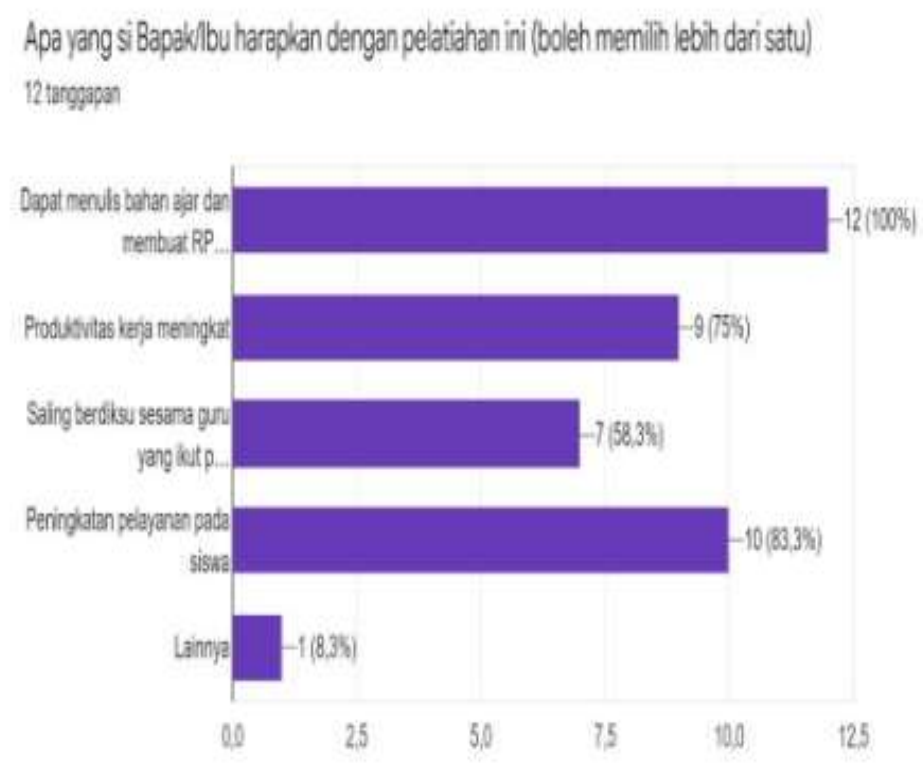

Gambar 1.Hasil Kuisioner Peserta Pelatihan

Pelatihan ini dilakukan untuk menyiasati strategi dalam meningkatkan kualitas pembelajaran dimasa pandemi Covid - 19 yang sedang melanda dunia tidak terkecuali Indonesia. Pada saat pandemi guru tetap harus memberikan pelayanan yang bermutu dan bermakna untuk para siswanya dalam memenuhi kebutuhan belajarnya, meskipun dilakukan dirumah masing-masing. Berdasarkan penelitian yang dilakukan oleh Handayani yang bertujuan untuk meningkatkan kompetensi guru dalam menyusun rpp dan pelaksanaan pembelajaran melalui teknik in house training (Handayani, 2019). Adapun penelitian lainnya dilakukan oleh Rangkuti bertujuan untuk meningkatkan kemampuan guru dalam menyusun Rencana Pelaksanaan 
Pembelajaran melalui Workshop di SDN 200212 Padangmatinggi (Rangkuti, 2019). Merujuk dari penelitian keduanya, pelatihan dalam penyusunan rencana pelaksanaan pembelajaran sangat efektif bagi guru dalam menyusun perangkat pembelajaran untuk menunjang keberhasilan pendidikan.

Terdapat kelemahan terhadap penerapan dalam kegiatan proses pembelajaran secara daring maupun luring bagi pihak SMKN 49 Dinas Provinsi Jakarta. Meskipun berada ditengah ibukota provinsi DKI Jakarta, masih terdapat beberapa siswa yang belum dapat merasakan pemerataan belajar dirumah secara daring, sebagian siswa ada yang tidak memiliki fasilitas untuk belajar seperti handphone dan sebagian siswa tidak memiliki kuota yang memadai dalam mengikuti pembelajaran secara daring. Oleh karenanya, guru dapat menyiasati hal tersebut dengan menggunakan bahan ajar berupa modul untuk siswa yang tidak memiliki handphone dan kuota internet yang terbatas. Dengan adanya modul tersebut diharapkan para siswa tetap dapat mengikuti materi pembelajaran sehingga tidak tertinggal dari teman siswa lainnya. Adapun kelemahan dalam kegiatan pengabdian kepada masyarakat ini adalah, ada beberapa peserta yang belum menulis rencana pelaksanaan pembelajaran yang dikirim melalui email dari tim pengabdian masyarakat.

Penyusunan rencana pelaksanaan pembelajaran dan bahan ajar yang harus dilakukan oleh guru tertuang didalam PP No. 19 Tahun 2005 yang tertuis bahwa: "perencanaan proses pembelajaran meliputi silabus dan rencana pelaksanaan pembelajaran yang memuat sekurang-kurangnya tujuan pembelajaran, materi ajar, metode pengajaran, sumber belajar, dan penilaian hasil belajar". Dalam Peraturan Menteri Pendidikan Nasional Nomor 16 Tahun 2007 juga dijelaskan bahwa guru wajib memiliki empat kompetensi, yang meliputi kompetensi pedagogik, kompetensi sosial, kompetensi kepribadian dan kompetensi profesional. Kompetensi pedagogik dan kompetensi profesional inilah yang membedakan guru dengan profesi lainnya. Usman (2002:22). Setiap guru pada satuan pendidikan berkewajiban menyusun RPP secara lengkap dan sistematis agar pembelajaran berlangsung secara interaktif, inspiratif, menyenangkan, menantang, memotivasi peserta didik untuk berpartisipasi aktif, serta memberikan ruang yang cukup bagi prakarsa, kreativitas, dan kemandirian sesuai dengan bakat, minat, dan perkembangan fisik serta psikologis peserta didik. Meskipun sudah banyak penelitian yang dilakukan terkait dengan pelatihan penyusunan rencana pelaksanaan pembelajaran dan bahan ajar bagi guru tetapi pada kenyataannya masih banyak guru yang masih kesulitan dalam menyusun RPP dan Bahan Ajar, sehingga pada kenyataan dilapangan dan sampai sekarang masih banyak proses pembelajaran belum tercapai dengan optimal. Dengan demikian penelitian selanjutnya adalah penerapan dalam menulis rencana pelaksanaan pembelajaran dan bahan ajar bagi guru dan akan dibimbing oleh tim pengabdian masyarakat.

\section{SIMPULAN DAN SARAN}

Hasil dari kegiatan pelaksanaan pengabdian masyarakat ini menunjukkan adanya peningkatan keterampilan dalam menyusun rencana pelaksanaan pembelajaran dan bahan ajar.

Program pelatihan ini merupakan suatu pendekatan yang efektif untuk dilakukan secara daring via zoom pada saat kondisi pandemi Covid-19 yang aktivitasnya dapat dilakukan meskipun dari rumah masingmasing. Sehingga para guru masih dapat beraktivitas dan melakukan pengawasan terhadap para siswanya melalui media internet.

\section{UCAPAN TERIMA KASIH}

Ucapan terima kasih kepada LPPM Universitas Negeri Jakarta yang telah memberikan bantuan dana sehingga terlaksananya kegiatan pengabdian masyarakat dengan baik dan lancar serta ucapan terimakasih kepada kepala sekolah beserta dewan guru SMK Negeri 49 Dinas Provinsi DKI Jakarta yang telah berpartisipasi dalam kegiatan pelatihan pengabdian masyarakat.

\section{DAFTAR PUSTAKA}

Basyiruddin, U. (2002). Media Pendidikan. Jakarta: Ciputat Press 
Depdiknas. (2003). UU RI No. 20 Tahun 2003 tentang Sistem Pendidikan Nasional. Jakarta: Depdiknas.

Depdiknas (2004). Standar Kompetensi Guru Sekolah Dasar. Jakarta: Depdiknas.

Depdiknas. (2005). UU RI No. 14 Tahun 2005 tentang Guru dan Dosen. Jakarta: Depdiknas.

Handayan, H. R, (2019). Peningkatan Kompetensi Guru Dalam Menyusun Rpp Dan Pelaksanaan Pembelajaran Melalui Teknik Iht (In House Training), Jurnal Ide guru, Vol. 4, No.1

Humas UNY. Workshop Daring Model Pembelajaran Masa Pandemi Covid - 19. 20 Juni 2020. https://www.uny.ac.id/berita/workshopdaring-model-pembelajaran-masa-pandemicovid-19. [di Akses 3 November 2020].

Indasari, S. R., Wijaya, A. W. A., Layuk, M., Sambo, M. S., dan Indrawati, M. (2020). Buku Saku Dukungan Psikososial Bagi Guru \& Siswa Tangguh di Masa Pandemi Covid-19, Tangerang Selatan: WVI

Kemdikbud. Suka duka dalam Proses Pembelajaran Melalui Metode Daring/Luring pada Masa Pandemi Covid19.

https://guruberbagi.kemdikbud.go.id/artikel/ kegiatan-ekonomi-masyarakat-pada-masapandemi-covid-19/, [di Akses 3 November 2020]
Komite Penanganan Covid-19 dan Pemulihan Ekonomi Nasional. https://covid19.go.id. [di Akses 3 November 2020]

Maharani, I., Fridani, L., dan Akbar, Z. (2019). Efektivitas Penggunaan Media Film Bertema Pendidikan Dalam Layanan Informasi Bimbingan Klasikal, Faktor Jurnal Ilmiah Kependidikan Vol. 6 No. 2

Publicemergency. WHO Coronavirus Disease (COVID-19) Dashboard. 12 September 2020.https://covid19.who.int, [di Akses 3 November 2020]

Rangkuti, N. (2019). Upaya Peningkatan Kemampuan Guru Dalam Melaksanaan Pembelajaran Berbasis Kompetensi Melalui Workshop Penyusunan RPP Di SD Negeri 200212 Padangmatinggi. Nusantara: Jurnal Ilmu Pengetahuan Sosial. Vol 6 No 3

Sulastri. (2019). Pelatihan Penyusunan

Perangkat Perencanaan Pembelajaran Kepada Para Guru. Journal of Community Services in Humanities and Social Sciences. Vol. 1 No. 1

Seniati, L., Yulianto, A., \& Setiadi, B. N. (2011). Psikologi Eksperimen. Jakarta: PT. Indeks.

Yanuarti, E. (2017). Peningkatan Kompetensi Pedagogik Guru (Penyusunan Rpp) Melalui Supervisi Akademik, Tajdidukasi, Volume VII, No. 1 Januari. 